\title{
Studi Deskriptif Pendidikan Karakter: Respect and Responsibility di SMP Negeri Kota Bandung
}

\author{
Imam Zaedi", Eneng Nurlaili Wangi
}

Prodi Ilmu Psikologi, Fakultas Psikologi, Universitas Islam Bandung, Indonesia.

*imamzaedii@gmail.com, nurlailiyunar@gmail.com

\begin{abstract}
Character education is education that shapes one's personality through character education, the results of which can be seen from good behavior, honesty, responsibility, respecting the rights of others, and so on. According to Lickona, there are two main moral values, namely respect and responsibility, so that these values represent the main moral basis that applies universally. This study aims to provide an overview and obtain empirical data regarding the description of respect and responsibility character education at SMP Negeri Bandung City. This study uses the Cluster Random Sampling technique. The measuring instrument used is Respect \&amp; Responsibility School Culture Survey for children and adults. The research method used is a descriptive study with a sample of 200 adult subjects and 450 child subjects. The results of this study indicate that, in the category of students, there is a high percentage of respect in aspects of $73.3 \%, 74.4 \%$ of responsibility aspects, and a moderate percentage of $66.4 \% \%$ on bullying. In the adult category, it has a high percentage of the respect aspect of $83 \%$, and the responsibility aspect of $82 \%$.
\end{abstract}

Keywords: Education, Character Education, Respect, Responsibility.

Abstrak. Pendidikan karakter merupakan pendidikan yang membentuk kepribadian seseorang melalui pendidikan budi pekerti, yang hasilnya terlihat dari tingkah laku yang baik, jujur, bertanggung jawab, menghormati hak orang lain, dan sebagainya. Menurut Lickona ada dua nilai moral utama yaitu respect dan responsibility, sehingga nilai-nilai tersebut mewakili dasar moralitas utama yang berlaku secara universal. Penelitian ini bertujuan untuk memberikan gambaran dan memperoleh data empiris mengenai gambaran pendidikan karakter respect and responsibility di SMP Negeri Kota Bandung. Penelitian ini menggunakan teknik Cluster Random Sampling. Alat ukur yang digunakan yaitu Respect \&amp; Responsibility School Culture Survey untuk anak dan dewasa. Metode penelitian yang digunakan adalah studi deskriptif dengan sampel subjek dewasa 200 orang dan subjek anak 450 orang. Hasil penelitian ini menunjukkan bahwa, pada kategori siswa memiliki persentase tinggi pada aspek respect sebesar $73,3 \%$, aspek responsibility $74,4 \%$, dan persentase sedang pada bullying sebesar $66,4 \% \%$. Pada kategori dewasa, memiliki persentase tinggi aspek respect sebesar $83 \%$, dan aspek responsibility $82 \%$.

Kata Kunci: Pendidikan, Pendidikan Karakter, Respect, Responsibility. 


\section{A. Pendahuluan}

Pendidikan adalah program yang terencana yang memiliki tujuan untuk dapat memberikan pengembangan bagi individu untuk menjadi lebih baik. Selain bertujuan untuk mengolah pikiran dan akal manusia untuk menjadi lebih baik, pendidikan juga bertujuan untuk dapat meningkatkan kualitas diri, karakter, dan moral (Nurmala et al., 2020). Menurut UndangUndang No. 20 tahun 2003 tentang Sistem Pendidikan Nasional yang menyatakan bahwa "Pendidikan nasional bertujuan untuk mengembangkan potensi peserta didik agar menjadi manusia yang beriman dan bertakwa kepada Tuhan Yang Maha Esa, berakhlak mulia, sehat, berilmu, cakap, kreatif, mandiri, dan menjadi warga negara yang demokratis, serta bertanggung jawab" (Purnomo, 2014).

Salah satu program pendidikan sekolah adalah Penguatan Pendidikan Karakter (PPK). Kegiatan ini melibatkan dukungan masyarakat dan kerja sama dengan sekolah, selain itu kegiatan tersebut juga melibatkan keluarga, serta publik, dimana kegiatan ini bertujuan untuk dapat memperkuat karakter siswa baik dari aspek kognitif maupun afektif. Melalui pendidikan karakter, diharapkan dapat mengubah perilaku siswa, cara bertindak, maupun cara berpikir seluruh siswa menjadi lebih baik dan berintegritas. Pendidikan karakter sendiri menekankan pada pembelajaran, pengertian, pemahaman, dan juga praktik langsung oleh siswa, hal ini dilakukan secara masif dan efektif melalui lembagaa pendidikan. Pendidikan karakter harus mulai ditanamkan sejak Pendidikan Anak Usia Dini (PAUD), kemudian ke jenjang berikutnya yaitu Sekolah dasar, lalu Sekolah Menegah Pertama dan Sekolah Menegah Atas (Novitasari et al., 2019).

Berdasarkan survei yang dilakukan di beberapa kota besar seperti Yogyakartaa, Surabaya, Bandung, Jakarta, Bekasi, Depok, dan Bali, dan Bogor, membuktikan bahwa 39\% dari 663 responden remaja menyatakan pernah melakukan hubungan sexual (Gunawan, 2012). Survei Pemetaan Daerah Rawan Penyalahgunaan dan Peredaran Gelap Narkoba menunjukkan bahwa di Indonesia jumlah pengguna narkoba sekitar 3.1 juta sampai 3.6 juta orang atau setara dengan 1.9\% dari populasi penduduk berusia 10-59 tahun di tahun 2008. Diperkirakan tingkat penyalahgunaan narkoba akan semakin marak dalam beberapa tahun kedepan. Hasil survei memperkirakan angka prevalensi penyalahgunaan narkoba akan meningkat sekitar 2,6\% di tahun 2013 (PUSLITDATIN, 2019). Survei lainnya yang dilakukan oleh Kemenkes RI (2014) mengenai kasus penyalahgunaan narkotika dan obat-obatan terlarang di Indonesia menunjukkan bahwa kasus narkoba semakin meningkat dari tahun ke tahun dan diprediksikan akan terus mengalami peningkatan, diketahui bahwa pengguna terbanyak yaitu berlatar belakang SMA dan SMP. Selain itu, sebuah studi menunjukkan bahwa 84\% anak-anak Indonesia pernah menjadi korban perundungan. Indonesia juga dinobatkan sebagai negara yang memiliki tingkat perundungan paling tinggi jika dibandingkan dengan negara-negara Asia lainya (Borualogo \& Gumilang, 2019). Masa remaja (adolescence) adalah perieode perkembangan perpindahan dari kanak - kanak menuju dewasaa, dimana banyak sekali perubahan baik kognitif, sosial, biologis dan emosional. Remaja memiliki tiga fase, yaitu awal, tengah, dan akhir (Santrock, 2012). Dalam penelitian ini difokuskan kepada remaja yang berada di fase awal dalam rentang usia dari 12-15 tahun atau yang sedang menduduki jenjang pendidikan Sekolah Menengah Pertama. Pada masa ini, aspek emosional yang dimiliki remaja mengalami goncangan yang besar, hal ini dikarengakan adanya perubahan jasmani yang pesat.

Beberapa fenomena yang terjadi di kalangan remaja menggambarkan bahwa kualitas karakter yang dimiliki oleh siswa masih belum dapat dikatakan baik (Setiawan, 2013). Sehingga dapat dijelaskan bahwa perilaku menyimpang seperti narkoba ataupun hubungan seksual artinya tidak menghargai dirinya sendiri ataupun menghargai orang lain. Oleh karena itu, penanaman karakter respect dan responsibility diperlukan untuk menjadi prioritas bangsa, karena hal ini sangatlah penting, Penanganan segera perlu dilakukan, hal ini wajib dilakukan dari berbagai komponen baik dari lingkungan sekolah, keluarga, pemerintah, lembaga pendidikan, masyarakat, dan tokoh agama dengan tujuan agar masyarakat Indonesia yang memiliki karakter yang bermartabat dan berbudaya (Ningsih, 2015). Berbagai alternatif yang dapat ditempuh untuk menangani permasalahan tersebut adalah melalui pendidikan, karena pendidikan dapat membantu meningkatkan karakter individu ke arah yang lebih baik, yaitu 
dengan adanya penerapan program pendidikan karakter melalui pendidikan formal ataupun nonformal, baik disekolah ataupun di lingkungan manapun. Salah satu program penguatan pendidikan karakter yang dicetuskan oleh Walikota Bandung Ridwan Kamil yaitu Bandung Masagi. Bandung Masagi sebagai salah satu program penguatan pendidikan karakter dinilai efektif dalam mengembangkan moral siswa, dengan cara menanamkan prinsip budaya sunda yang bertujuan untuk mengamalkan kehidupan, diantaranya silih asih, silih asaah, siliih asuh, dan siliih wawangi. Seluruhnya diwujudkan program jaga budaya, cinta agama, bela negara dan cinta terhadap lingkungan (Dinas Pendidikan, 2017). Berdasarkan penelitian yang telah dilakukan oleh Sita Aulia Rahmah (2019) menyatakan bahwa program Bandung Masagi sudah sangat efektif dalam meningkatkan karakter siswa, terbukti dengan adanya perubahan perilaku ke arah yang lebih baik.

Selain itu berdasarkan hasil wawancara yang didapatkan oleh peneliti terhadap beberapa guru dari berbagai SMP di Kota Bandung, tentang program Pendidikan karakter yang sudah diterapkan di beberapa sekolah tersebut seperti sekolah sudah berupaya dalam menerapkan perilaku hormat dan tanggung jawab dengan sebaik mungkin seperti menjalankan program 5S (sapa, senyum, salam, sopan, dan santun), membiasakan untuk mengucapkan kata tolong, maaf dan terimakasih, melakukan sholat dhuha bersama, serta anjuran untuk membuang sampah pada tempatnya. Dengan adanya pembiasaan tersebut membuat siswa terbiasa dalam menerapkan sikap hormat dan tanggung jawab dalam kehidupan sehari-hari. Pentingnya pendidikan karakter di sekolah terutama di masa-masa remaja karena pendidikan karakter dapat membangun karakter remaja menuju ke arah yang lebih baik. Selain itu, perkembangan invididu baik sosial, emosional, dan etis, dapat dibentuk melalui pendidikan karakter (Suhilmiati, 2017).

Pendidikan karakter menurut Thomas Lickona adalah pendidikan untuk membentuk kepribadian seseorang, yang berdampak pada peningkatan tingkah laku yang baik, jujur , bertanggung jawab atas dirinya maupun orang lain, hormat kepada yang lebih tua, semangat, bekerja keras, menghormati dan mengghargai orang lain dan hak orang lain (Julaiha, 2014). Menurut Thomas Lickona, hendaknya pendidikan karakter memiliki tiga bagian yang saling terkait yaitu; moral knowing, moral feeling, and moral behavior (Lickona, 2013).

Menurut Lickona ada dua nilai moral utama yaitu rasa hormat (respect) dan tanggung jawab (responsibility). Dua nilai tersebut nilai moral dasar yang wajib untuk ditekankan dan diterapkan di sekolah. Beberapa nilai yang lain seperti nilai kejujuran, keadilan, toleransi, kebijaksanaan, disiplin diri, tolong menolong, peduli sesama, kerjasama, keberanian, dan sikap demokratis merupakan bentuk dari rasa hormat dan tanggung jawab ataupun sebagai media pendukung untuk bersikap hormat dan bertanggung jawab (Junaidi \& Kun Prasetyo, 2016). pendidikan karakter respect dan responsibility di sekolah, dapat memberikan hasil yang baik terhadap siswa dalam berbagai hal, seperti adanya peningkatan dari segi perilaku sosial maupun prestasi siswa.

Seperti pada percobaan penerapan program 3R yang pertama kali diterapkan oleh Dr. John O'Connell pada akhir tahun sembilan puluhan, program tersebut berfokus pada "respect, responsibility, and the right to learn". Dalam penerapannya, hasil menunjukkan bahwa tingkat kedisiplinan terus meningkat, kemudian terjadi peningkatan secara terus menerus terkait dengan prestasi akademik siswa. Dalam hal ini, O'Connell menyatakan bahwa menciptakan lingkungan yang aman dan tertib, saling menghormati, perilaku sopan dan bertanggung jawab adalah pondasi dimana keberhasilan akademis berkelanjutan akan di bangun (Lickona, 2012). Selain itu, penelitian yang dilakukan oleh Covell \& Howe (2011) mengenai pendidikan nilai moral melalui: hak, rasa hormat dan tanggung jawab menunjukkan bahwa RRR telah sepenuhnya dipeluk dan dimasukkan di seluruh sekolah, ada peningkatan dalam domain sosial, perilaku, dan kognitif siswa. Dibandingkan dengan siswa di sekolah di mana RRR kurang diterapkan sepenuhnya. Dalam domain sosial, siswa dilaporkan memperlakukan siswa, staf, dan guru lain dengan lebih hormat. Dalam domain perilaku, siswa dilaporkan secara umum kurang agresif dan tidak terlalu mengganggu di kelas, sebaliknya menunjukkan perilaku yang lebih kooperatif dan membantu (Covell \& Howe, 2011).

Rasa hormat merupakan salah satu permasalahan yang sangat besar. Jika individu 
mampu menghargai dirinya sendiri dan menghormati orang lain, maka individu akan mengetahui makna benar dan salah, yang mana pada akhirnya akan menentukan dan membentuk individu yang bertanggung jawab, yang tercermin sebagai individu yang produktif dan tidak terlibat dalam kejahatan. Oleh karena itu, penerapan rasa hormat perlu dikembangkan oleh sekolah agar mampu menghasilkan siswa yang bertanggung jawab. Dengan begitu, rasa tanggung jawab akan menghindarkan siswa dari tindakan perilaku menyimpang yang marak terjadi saat ini (Hammett \& Staeheli, 2011).

\section{B. Metodologi Penelitian}

Terdapat dua macam nilai yang utama dalam kehidupan, yaitu hormat dan tanggung jawab Hormat menunjukkan penghargaan terhadap harga diri orang lain maupun pada hal lain. Nilai respek memiliki tiga hal penting yaitu; penghormatan kepada diri sendiri, pada orang lain, dan pada semua bentuk kehidupan dan lingkungan yang saling mendukung satu sama lain. Penghargaan kepada diri sendiri, mewajibkan manusia untuk memperlakukan yang dihadapi dalam kehidupannya sebagai individu yang memiliki nilai. Penghormatan kepada orang lain, mewajibkan manusia untuk memperlakukan seluruh manusia termasuk orang-orang yang dibenci menjadi individu yang memiliki nilai serta menyetarakan dengan nilai dirinya sendiri. Kedua hal tersebut inti dari Golden rule yang memiliki makna "Perlakukanlah orang lain sebagaimana engkau memperlakukan dirimu sendiri". Penghormatan kepada semua bentuk kehidupan dan lingkungan, dapat dijelaskan bahwa tindakan kasar yang dilakukan terhadap hewan juga menjadi sesuatu yang dilarang sehingga diharuskan untuk berlaku baik dengan cara melindungi alam dan lingkungan (Lickona, 1991).

Tanggung jawab adalah bentuk lanjutan dari respek. Jika seseorang menghormati orang lain, itu artinya dia menghargai mereka. Jika seseorang tersebut menghargai mereka, artinya dia merasakan sebuah ukuran dari rasa tanggung jawabnya untuk menghormati kesejahteraan hidup mereka. Tanggung jawab secara literal berarti "kemampuan untuk merespon atau menjawab". Tanggung jawab menitikberatkan pada kewajiban yang positif untuk saling menjaga satu sama lain, sementara respek lebih menitikberatkan pada kewajiban yang terkadang berbentuk kalimat negatif. Secara umum tanggung jawab juga berarti mengambil keputusan yang patut dan efektif. Karakter tanggung jawab yang dimaksud adalah sikap hidup yang melaksanakan tugas dan kewajiban secara sungguh-sungguh dengan sebaik mungkin, sesuai peranannya sebagai makhluk individu maupun makhluk sosial di masyarakat dan siap menerima konsekuensi terhadap perbuatan yang telah dilakukan. Karakter tanggung jawab siswa di kelas dapat terwujud dalam bentuk perilaku sebagai berikut, melaksanakan tugas yang diberikan guru dengan sebaik-baiknya, menjaga kebersihan kelas, mengembalikan buku dan alat pembelajaran yang telah dipinjam dari guru. Tanggung jawab di lingkungan sekolah, misalnya menjaga kebersihan sekolah dengan membuang sampah pada tempatnya. Tanggung jawab lainnya berupa kesiapan dalam menerima konsekuesi terhadap perbuatan yang dilakukan seperti mengganti buku yang hilang akibat dari kelalaiannya (Junaidi \& Kun Prasetyo, 2016).

Penelitian ini menggunakan desain studi deskriptif dengan pendekatan kuantitatif, karena tujuan dari penelitian ini adalah untuk melihat dan mendeskripsikan gambaran dari suatu fenomena. Menurut Sugiyono (2017), pengertian kedua penelitian tersebut adalah sebagai berikut: penelitian deskriptif adalah penelitian yang dilakukan untuk mengetahui nilai variabel baik satu variabel atau lebih (independen) tanpa membuat perbandingan atau hubungan dengan variabel lain. Dalam penelitian ini, metode deskriptif digunakan untuk mengetahui dan mengkaji bagaimana pendidikan karakter di SMP Negeri yang ada di Kota Bandung. Sedangkan, pendekatan kuantitatif menurut Sugiyono (2017) digunakan untuk meneliti pada populasi atau sampel tertentu, pengumpulan data menggunakan instrumen penelitian, analisis data bersifat kuantitatif atau statistik (Sugiyono, 2017).

Alat ukur yang digunakan dalam penelitian ini yaitu Respect \& Responsibility School Culture Survey yang disusun oleh Davidson, Lickona, dan Khmelkov, (2004). Peneliti menggunakan alat ukur yang sudah diadaptasi ke dalam bahasa Indonesia oleh Nurlaili Wangi, Dewi Rosiana, Nanan Nuraini dan Yuli Aslamawati (2020) (Ramadhan \& Rosiana, 2017). 
Pengambilan data dilakukan dengan menyebarkan link google form yang diberikan kepada perwakilan guru pada tiap SMP Negeri yang menjadi sampel penelitian. Selanjutnya, masingmasing perwakilan guru akan menyebarkan link google form kepada siswa. Kuisioner terdiri dari untuk anak terdiri dari 21 item, dan untuk dewasa terdiri dari 15 item yang mengukur bagaimana persepsi siswa, guru, staf sekolah, dan orang tua terhadap budaya sekolah mengenai sejauh mana orang lain di lingkungan sekolah menunjukkan perilaku saling menghargai dan bertanggung jawab. Adapun jumlah sampel yang didapatkan, yaitu sebanyak 650 terdiri dari 450 siswa dan 200 guru,staf, dan orangtua siswa berasal dari 12 SMPN di Kota Bandung. dengan cara mendeskripsikan atau menggambarkan data yang telah terkumpul dari kuesioner dan hasil wawancara, sebagaimana adanya tanpa bermaksud membuat kesimpulan yang berlaku untuk umum atau generalisasi. Data yang diperoleh berupa skala ordinal. Data yang disajikan dalam distribusi frekuensi berbentuk tabel dan diagram, yang telah diolah dengan bantuan program SPSS versi 23 .

\section{Hasil Penelitian dan Pembahasan}

Tabel 1. Persentase Kategorisasi Peraspek Respect and Responsibility Untuk Anak

\begin{tabular}{lccc}
\hline \multirow{2}{*}{ Kategori } & \multicolumn{3}{c}{ Total } \\
\cline { 2 - 4 } & Menghargai & Tanggung Jawab & Bullying \\
\hline Tinggi & \% & \% & \% \\
Sedang & 73.3 & 74.4 & 16.9 \\
Rendah & 25.8 & 25.6 & 66.4 \\
& 0.9 & 0 & 16.7 \\
\hline Catatan. N=450 & & &
\end{tabular}

Pada aspek respect subjek anak berada pada kategori tinggi yang dapat diartikan sebagai sikap hormat yang ditampilkan oleh siswa dapat terlihat dari perilaku saling menghormati antar sesama tanpa membedakan satu sama lain, terlebih kepada orang yang lebih tua. Selain itu, para siswa senantiasa bersikap sopan terhadap orang lain dengan cara bertutur kata yang baik serta mengatakan permisi atau tolong ketika meminta bantuan, senantiasa untuk mengucapkan terimakasih kepada siapapun, serta bersikap peka ketika orang lain sedang butuh bantuan ataupun mendapat kesulitan. Dalam hal ini, baik guru, orang tua, maupun siswa saling menganggap bahwa satu sama lain memiliki sikap saling menghormati dan menghargai antar sesama.

Pada aspek responsibility subjek anak berada pada kategori tinggi dapat diartikan bentuk tanggung jawab yang ditampilkan oleh siswa dapat terlihat dari perilaku siswa yang mampu dalam mengatasi ataupun menyelesaikan masalah dengan cara yang baik, serta senantiasa menampilkan sikap tolong menolong dan saling membantu terhadap siapapun yang membutuhkan bantuan atau sedang dalam masalah.

Kategori sedang pada aspek perundungan menunjukkan bahwa, walaupun siswa, orang tua, ataupun guru seringkali memiliki tanggung jawab yang tinggi dengan cara menanggapi dan mengatasi masalah perundungan dengan baik, namun perilaku mengejek, mengucilkan, dan perilaku negatif yang dilakukan secara verbal lainnya masih sering terjadi di kalangan siswa. Selain itu, terkadang tanpa disadari orang dewasa melakukan sesuatu yang ternyata dapat menyakiti siswa secara emosional. Dalam hal ini, perlu adanya kesadaran dari berbagai pihak mengenai perilaku-perilaku yang terkait dengan masalah perundungan. 
Tabel 2. Persentase Kategorisasi Peraspek Respect and Responsibility Untuk Dewasa

\begin{tabular}{lcc}
\hline \multirow{2}{*}{ Kategori } & \multicolumn{2}{c}{ Interval Skor } \\
\cline { 2 - 3 } & Menghargai & Tanggung Jawab \\
\hline Tinggi & $\%$ & $\%$ \\
Sedang & 83 & 82 \\
Rendah & 16 & 18 \\
& 1 & 0 \\
\hline
\end{tabular}

Catatan. $\mathrm{N}=200$

Pada aspek Respect subjek dewasa berada pada kategori tinggi yang dapat diartikan bahwa sikap hormat yang ditunjukkan oleh orang dewasa dapat tercermin dari perilaku guru dan orangtua yang sudah menjadi teladan yang baik bagi anak, dengan cara memberikan contoh dalam menunjukkan perilaku hormat kepada orang lain, senantiasa bersikap sopan terhadap siapapun tanpa memandang usia, serta bersikap adil dalam memberikan pelajaran bagi pihak yang salah dan memberikan apresiasi bagi pihak yang benar. Dalam hal ini, baik guru, orang tua, maupun siswa saling menganggap bahwa satu sama lain memiliki sikap saling menghormati dan menghargai antar sesame. Pada aspek Responsibility subjek dewasa berada pada kategori tinggi yang dapat diartikan bahwa antara subjek dewasa maupun anak sudah mampu dalam menjaga diri sendiri maupun orang lain dan mampu bertanggung jawab dalam menjalankan segala bentuk kewajiban.

Adapun bentuk-bentuk tanggung jawab yang ditampilkan orang dewasa yaitu senantiasa memberikan dorongan kepada siswa untuk menunjukkan perilaku yang baik, salah satunya dengan cara memberikan contoh dan menjadi teladan yang baik ataupun memberikan nasihat serta motivasi agar siswa memiliki semangat untuk menampilkan perilaku yang baik, selalu mengajarkan kepada siswa untuk selalu melakukan sesuatu yang positif ketika melakukan kesalahan, seperti meminta maaf atau melakukan sesuatu yang baik kepada orang tersebut. Hal ini sesuai dengan toeri dari Lickona (1991) yang menjelaskan tentang guru sebagai pengasuh, mentir dan contoh terhadap muridnya.

Tabel 3. Hasil Pengolahan Data Berdasarkan Jenis Kelamin Subjek Anak Pada Aspek Menghargai

\begin{tabular}{|c|c|c|c|c|c|c|c|c|}
\hline \multirow{3}{*}{$\begin{array}{c}\text { Jenis } \\
\text { Kelamin }\end{array}$} & \multicolumn{8}{|c|}{ Kategori } \\
\hline & \multicolumn{2}{|c|}{ Rendah } & \multicolumn{2}{|c|}{ Sedang } & \multicolumn{2}{|c|}{ Tinggi } & \multicolumn{2}{|c|}{ Total } \\
\hline & $\mathbf{n}$ & $\%$ & $\mathbf{n}$ & $\%$ & $\mathbf{n}$ & $\%$ & $\mathbf{n}$ & $\%$ \\
\hline Laki-Laki & 1 & 0.2 & 51 & 11.3 & 102 & 22.7 & 154 & 34.2 \\
\hline Perempuan & 3 & 0.7 & 65 & 14.4 & 228 & 50.7 & $\begin{array}{c}29 \\
6\end{array}$ & 65.8 \\
\hline
\end{tabular}


Tabel 4. Hasil Pengolahan Data Berdasarkan Jenis Kelamin Subjek Anak Pada Aspek Tanggung Jawab

\begin{tabular}{|c|c|c|c|c|c|c|c|c|}
\hline \multirow{3}{*}{$\begin{array}{c}\text { Jenis } \\
\text { Kelamin }\end{array}$} & \multicolumn{8}{|c|}{ Kategori } \\
\hline & \multicolumn{2}{|c|}{ Rendah } & \multicolumn{2}{|c|}{ Sedang } & \multicolumn{2}{|c|}{ Tinggi } & \multicolumn{2}{|c|}{ Total } \\
\hline & $\mathbf{F}$ & $\%$ & $\mathbf{F}$ & $\%$ & $\mathbf{F}$ & $\%$ & $\mathbf{F}$ & $\%$ \\
\hline Laki-Laki & 0 & 0 & 39 & 8.7 & 115 & 25.6 & 154 & 34.2 \\
\hline Perempuan & 0 & 0 & 76 & 16.9 & 220 & 48.9 & 296 & 65.8 \\
\hline
\end{tabular}

Berdasarkan data yang diperoleh, dapat diketahui bahwa aspek menghargai dan tanggung jawab pada kategori tinggi, lebih banyak dimiliki oleh siswa perempuan (lihat Table $3 \&$ Tabel 4). Hal ini dapat dijelaskan berdasarkan penelitian yang dilakukan oleh Hardoko (2009) dan Hasanah (2020), yang menunjukkan bahwa siswa perempuan memiliki kematangan moral dan kepedulian sosial yang lebih tinggi daripada laki-laki. Diketahui bahwa anak perempuan lebih memiliki sopan santun yang tinggi dalam bertindak. Hal tersebut dikarenakan anak perempuan lebih patuh pada aturan, sedangkan laki-laki memiliki tingkat sopan santun yang lebih rendah, kemungkinan karena anak laki-laki memang sudah memiliki naluri untuk bertindak sesuai keinginannya dan lebih agresif (Hasanah, 2020).

Berdasarkan hasil dari pengolahan data pada subjek dewasa dan anak didapatkan kesimpulan bahwa guru/staf serta orangtua sudah berhasil menjadi model untuk dicontoh dalam beretika yang menunjukkan rasa hormat serta tanggung jawab, baik ketika di sekolah maupun di luar sekolah. Begitu juga dengan siswa sebagian besar termasuk pada kategori tinggi, sehingga dapat dianggap bahwa siswa sudah dapat menunjukkan sikap saling menghargai, menghormati, dan peduli antar sesama.

Hal tersebut juga dapat di dukung oleh penelitian yang dilakukan oleh Iin Isna Sofiana (2019) mengenai implementasi nilai pendidikan karakter, Mei Wulandarizqy (2015) mengenai perilaku pendididikan karakter tanggung jawab, dapat diketahui bahwa perilaku hormat dan tanggung jawab itu dapat berhasil ketika orang dewasa dapat menjadi contoh yang baik untuk anak ataupun muridnya. Hasil penelitian menunjukkan bahwa pada aspek hormat dan tanggung jawab pada kategori dewasa berada pada kategori tinggi, maka dapat diartikan bahwa orang dewasa sudah berhasil untuk menghormati dan bertanggung jawab terhadap diri sendiri maupun orang lain yang dapat dijadikan contoh bagi anak ataupun muridnya.

Hasil yang serupa juga ditemukan pada penelitian yang dilakukan oleh Covell \& Howe (2001) mengenai pendidikan nilai moral yaitu hak, rasa hormat, dan tanggung jawab, temuan tersebut menunjukkan bahwa ada peningkatan dalam domain sosial, perilaku, dan kognitif siswa ketika sekolah telah sepenuhnya menerapkan RRR. Dalam domain sosial, siswa dilaporkan memperlakukan siswa, staf, dan guru lain dengan lebih hormat. Dalam domain perilaku, siswa dilaporkan secara umum kurang agresif dan tidak terlalu mengganggu di kelas, sebaliknya menunjukkan perilaku yang lebih kooperatif dan membantu (Covell \& Howe, 2011).

Sehingga, dengan adanya gambaran pada aspek hormat dan tanggung jawab yang berada pada kategori tinggi, diharapkan mampu meningkatkan perilaku dan sikap siswa ke arah yang lebih positif, serta menampilkan perilaku yang saling menghormati dan menghargai antar sesame agar tercipta lingkungan yang baik dengan mengutamakan nilai karakter sebagai dasar moral dalam menjalankan kehidupan bersama. 


\section{Kesimpulan \\ Respect}

Pada aspek ini diperoleh $83 \%$ subjek dewasa berada pada kategori tinggi dan $73.3 \%$ subjek anak berada pada kategori tinggi. Hal tersebut menunjukkan bahwa subjek dewasa maupun anak (siswa) telah menjalankan perilaku menghargai dan menghormati diri sendiri dan juga lingkungannya serta subjek dewasa sudah mengajarkan perilaku tersebut kepada siswa sehingga aspek ini perlu dipertahankan dan ditingkatkan.

\section{Responsibility}

Pada aspek ini diperoleh $82 \%$ subjek dewasa berada pada kategori tinggi dan $74.4 \%$ subjek anak berada pada kategori tinggi. Hal tersebut menunjukkan bahwa subjek dewasa maupun anak (siswa) telah menjalankan perilaku bertanggung jawab, membantu serta memberikan dukungan kepada orang lain, sehingga aspek ini perlu dipertahankan dan ditingkatkan.

\section{Bullying}

Pada aspek bullying diperoleh $66.4 \%$ subjek anak berada pada kategori sedang. Artinya, bahwa subjek anak pernah melihat dan mengalami tindakan bullying, namun sebagian anak sudah dapat menghindari perilaku bullying tersebut.

\section{Acknowledge}

Atas rasa syukur yang tiada henti dan rasa terima kasih yang teramat sangat, dari lubuk hati yang terdalam, peneliti ingin menyampaikan banyak terima kasih sebagai bentuk penghargaan yang sebesar-besarnya kepada pihak-pihak yang telah terlibat maupun ikut berkontribusi atas terlaksananya penelitian ini. Semoga sumbangan pengetahuan yang dihasilkan dari penelitian ini dapat bermanfaat bagi semua.

\section{Daftar Pustaka}

[1] Borualogo, I. S., \& Gumilang, E. (2019). Kasus Perundungan Anak di Jawa Barat: TemuanAwal Children's Worlds Survey di Indonesia. Psympathic: Jurnal Ilmiah Psikologi, 6(1), 15-30. https://doi.org/10.15575/psy.v6i1.4439Covell, K., \& Howe, R. B. (2011). Moral Education Through The 3 Rs: Rights, Respect, and Responsibility. Journal of Moral Education, 30(1), 29-41. https://doi.org/10.1080/03057240120033794

[2] Dinas Pendidikan. (2017). Pendidikan Karakter Bandung Masagi. https://disdik.bandung.go.id/ver3/pendidikan- karakter-bandung-masagi/

[3] Gunawan, H. (2012). Pendidikan Karakter: Konsep dan Implementasi. Alfabeta.

[4] Hasanah, A. (2020). Perbedaan perkembangan moral anak laki-laki dan anak perempuan pada usia sekolah dasar (analisis psikologi perkembangan). Jurnal Studi Islam, Gender, Dan Anak, 15(1), 41-57. https://doi.org/10.24090/yinyang.v15i1.3442

[5] Lickona, T. (1991). Educating for character: How our schools can teach respect and responsibility. Bantam Books.

[6] Lickona, T. (2012). Character Matters. PT. Bumi Aksara.

[7] Lickona, T. (2013). Educating For Caracter: How Our Scholle Can Teach Respect and Responsibility. Bumi Aksara.

[8] Ningsih, T. (2015). Implementasi Pendidikan Karakter. STAIN Press.

[9] Nurmala, A., Sobari, A., Agama, F., Universitas, I., Khaldun, I., \& Bogor, K. (2020). Tanggung Jawab Dalam Perspektif Guru the Relation of Education To Discipline and Responsibility Characters in the Teachers '. 7(1), 10-19.

[10] Purnomo, S. (2014). Pendidikan Karakter Di Indonesia: Antara Asa Dan Realita. Jurnal Kependidikan, 2(2), 66-84. ht

[11] Santrock, J. . (2002). Adolescence Perkembangan Remaja. Erlangga.

[12] Santrock, J. . (2012). Life-Span Development (Perkembangan Masa Hidup) (B. Widyasinta (ed.); 13th ed.). Erlangga.

[13] Setiawan, D. (2013). Peran Pendidikan Karakter Dalam Mengembangkan Kecerdasan Moral. Jurnal Pendidikan Karakter, 3(1), 53-63. https://doi.org/10.21831/jpk.v0i1.1287 
92 | Imam Zaedi, et al.

[14] Sudrajat, A. (2011). Mengapa Pendidikan Karakter. Jurnal Pendidikan Karakter, I(1), 47-58. https://doi.org/10.21831/jpk.v1i1.1316

[15] Sugiyono. (2017). Metode Penelitian Kuantitatif, Kualitatif, dan R\&D. Alfabeta, CV. htps://doi.org/10.24090/jk.v2i2.553

[16] Purnomo, S. (2014). Pendidikan Karakter Di Indonesia: Antara Asa Dan Realita. Jurnal Kependidikan, 2(2), 66-84. https://doi.org/10.24090/jk.v2i2.553

[17] Junaidi, J., \& Kun Prasetyo, Z. (2016). Pengaruh Subject Specific Pedagogy Tematik Terhadap Karakter Hormat Dan Tanggung Jawab Pada Siswa Kelas Iii Sekolah Dasar. Jurnal Pendidikan Karakter, 1, 23-35. https://doi.org/10.21831/jpk.v0i1.8610

[18] Hasanah, A. (2020). Perbedaan perkembangan moral anak laki-laki dan anak perempuan pada usia sekolah dasar (analisis psikologi perkembangan). Jurnal Studi Islam, Gender, Dan Anak, 15(1), 41-57. https://doi.org/10.24090/yinyang.v15i1.3442

[19] Husni, R. dan E. N. (2015). Deliberalisasi Pendidikan Karakter "Respect And Responsibility" Thomas Lickona. Tawazun: Jurnal Pendidikan Islam, 8(2), 257-274. http://ejournal.uika-bogor.ac.id/index.php/TAWAZUN/article/view/1129. 